\title{
ZONE REFINING OF ZIRCONIUM IN AN ELECTRIC FIELD
}

\author{
O.E. Kozhevnikov, M.M. Pylypenko, Yu.S. Stadnik, R.V. Azhazha \\ National Science Center "Kharkov Institute of Physics and Technology", Kharkiv, Ukraine \\ E-mail: kozhevnikov@kipt.kharkov.ua
}

The physical grounds and an experimental study of the efficiency of applying the zone recrystallization method in an electric field for zirconium refining from metal and gas-forming impurities are presented. The changes in the elemental composition, microhardness, and structure of the obtained ingots was investigated. It is shown that the application of the method can significantly reduce the content of interstitial impurities. Zirconium samples with a purity of $99.91 \mathrm{wt} . \%$ were obtained.

\section{INTRODUCTION}

In the next 50 years, the thermal neutron reactors will continue to occupy a dominant position among nuclear power units. The base material for the active zones of such reactors are zirconium-based alloys, which have an optimal combination of nuclear, corrosion, mechanical, thermal and other physicochemical characteristics [1,2].

The perfectioning of zirconium materials makes possible to increase the efficiency of existing power units, increase the fuel burnup depth, ensure operational reliability and safety of nuclear installations, and extend their design life.

The impurities in zirconium and its alloys, such as $\mathrm{O}, \mathrm{C}, \mathrm{Si}, \mathrm{P}, \mathrm{Mg}, \mathrm{K}, \mathrm{Ca}, \mathrm{Cl}, \mathrm{F}, \mathrm{Ni}, \mathrm{H}$, etc., even in small quantities, have a negative effect on the structure, physical and mechanical characteristics. This can lead to a change in the mechanical and corrosion properties of materials, to a change in the deformation and heat treatment modes.

The development of new alloys and improvement of the characteristics of existing zirconium alloys are impossible without an in-depth study of the processes for producing high purity zirconium. In this connection, it is necessary to study the patterns of behavior of metallic impurities and interstitial impurities during the process of obtaining zirconium by physical methods, as well as to study the effect of impurity composition on the characteristics of the material.

The process of crystallization from melt is one of the basic ways of refining metals and semiconductor materials. Typically, they are used on the final stage for purification from low concentrations of impurities. During the zone melting (ZM) of refractory metals in a vacuum it is takes place a refining as a result of the impurity separation between the melt and the solid phase during directional crystallization, as well as due to the evaporation of volatile impurities.

An electrotransport is used to deep refining of metals in the solid and liquid states. The method is based on the ability of the solution components to the directional displacement under an applied electric direct current.

The aim of this work was the physical grounds and experimental study of the impurity behavior in during the zirconium refining process by zone recrystallization method in an electric field (ZMEF), the obtaining high purity zirconium specimens and studying its structure and microhardness.

\section{MATERIALS AND RESEARCH METHODS}

The principle of zone refining is based on the different solubility of impurities in the liquid and solid phases of the base material. An important characteristic in the process description is the impurity distribution coefficient is $k$, which is the ratio of the impurity concentration in the solid phase $C_{S}$ to the concentration in the melt $C_{L}$ [3]:

$$
k=C_{S} / C_{L}
$$

It is distinguish between the concepts of equilibrium distribution coefficient $k_{0}$ and effective distribution coefficient $k_{e}$. The equilibrium coefficient $k_{0}$ is usually determined from the "base-impurity" state diagrams or by the ratio of the maximum solubility of an impurity to its concentration at the point of invariant transformation. However, with such estimation methods, $k_{0}$ values can be calculated only in the case of a significant concentration of impurities in the base material.

When calculating the equilibrium distribution coefficient $k_{0}$ in the case of low impurity concentrations it is convenient to use the theoretical methods of calculations based on the thermodynamic constants of the equation of ideal solutions. According to this concept it be can use the Schroeder-Le Chatelier equation:

$$
\ln \frac{C_{L}}{C_{S}}=-\frac{\Delta H}{R}\left(\frac{1}{T_{b}}-\frac{1}{T_{G}}\right)=\theta .
$$

Then

$$
\frac{C_{L}}{C_{S}}=e^{\theta} \text { and } k_{0}=1 / e^{\theta} .
$$

In the formula (2) $C_{L}$ and $C_{S}$ are the concentration values of the impurity in the liquid and solid phases of the main component, $\Delta H$ is the molar heat of fusion of the impurity $(\mathrm{J} / \mathrm{mol}), \mathrm{R}$ is the universal gas constant $(\mathrm{R}=8.314 \mathrm{~J} /(\mathrm{mol} \cdot \mathrm{K})), T_{b}$ is the melting temperature of the basic substance, $T_{G}$ is the estimated value of the melting temperature of the base-impurity alloy, which is selected from the state diagram.

For phase diagrams characterized by a continuous series of solid solutions, peritectic-type diagrams throughout the concentration range, as well as for impurities whose diagrams with the base metal are unknown, $T_{G}$ is chosen equal to the melting temperature of the impurity element. In the case of phase diagrams with a number of eutectic and peritectic transformations value $T_{G}$ is selected in order to meet the minimum 
transformation temperature of eutectic or peritectic type [4].

When conducting zone melting process, moving solidification front pushes dissolved impurity faster than it can evenly distributed in the melt. Before crystallization front occurs enriched impurity region called the diffusion layer. The diffusion layer thickness $\delta$ is dependent on the impurity diffusion capacity, the melt viscosity, the nature of the fluid motion, and the crystallization speed and it can be changed depending on the conditions of the melt mixing.

Therefore, the main characteristic of zone impurity separation process is the effective distribution coefficient $k_{e}$, which can be expressed by the BurtonPrim-Slichter formula [3]:

$$
k_{e}=\frac{1}{1+\left(\frac{1}{k_{0}}-1\right) \cdot e^{-\frac{v \delta}{d}}},
$$

where $v$ is the zone speed, $\delta$ is the diffusion layer thickness, and $d$ is the impurity diffusion coefficient in the melt.

The value of the diffusion coefficient $d$ for most metals is equal $5 \cdot 10^{-5} \mathrm{~cm}^{2} / \mathrm{s}$ approximately. The depth of the diffusion layer $\delta$ in the case of moderate mixing of the melt in the liquid zone is assumed to be $0.01 \mathrm{~cm}$. Therefore, $\delta / d \approx 200 \mathrm{~s} / \mathrm{cm}$. The ratio $v \delta / d$ is called the reduced crystallization rate and is a dimensionless quantity.

Having determined the $k_{0}$ values by formula (2), it becomes possible to calculate the value of the effective separation coefficient of the impurity $k_{e}$ according to formula (3).

In the case of the melting of refractory metals in vacuum it is occurs the refining process by substance separating during recrystallization and evaporation process of gas-formative impurities (oxygen, carbon, nitrogen, hydrogen) as well as from those metallic charge; $\mathrm{n}$ is the concentration of conduction ions; $L$ is the mean free pass of electron; $\sigma$ is the cross-section for scattering of electrons; $E$ is the electric field intensity; $Z^{*}$ is the effective ion charge $\left(Z^{*}=Z-|e| n L \sigma\right)$.

The value of $Z^{*}$ can be determined from the expression:

$$
Z^{*}=\frac{U k T}{D e},
$$

where $U$ is the ion mobility; $D$ is the ion self-diffusion coefficient; $T$ is the temperature; $k$ is the Boltzmann constant [10].

Depending on the sign of $Z^{*}$, the resultant force $F$ can be directed to the cathode $\left(Z^{*}>0\right)$, to the anode $\left(Z^{*}<0\right)$ or to be equal to zero $\left(Z^{*}=0\right)$.

The value of the impurity ion mobility $U$ is dependent on the properties of system and the temperature. In general, the relative mobility of ions is determined by the expression $\Delta U=\left(v_{1}^{\prime}-v_{2}^{\prime}\right) / E$, where $v_{1}^{\prime}$ and $v_{2}^{\prime}$ are the movement speeds of the impurity ions and a main component, respectively; $E$ is the electric field intensity. In the case of dilute solutions the speed of solvent movement $v_{2}^{\prime}$ is actually equal to zero, and impurities which have a high vapor pressure at the melting temperature of the base material. The pressure of saturated zirconium vapor at a melting point $T_{b}=2125 \mathrm{~K}$ is $2.6 \cdot 10^{-3} \mathrm{~Pa}$. The steam tension of a large number of metals at temperatures above $2000 \mathrm{~K}$ reaches $10 \ldots 10^{4} \mathrm{~Pa}$, which leads to their intense evaporation [5].

In work [6] the purification results of iodide zirconium by crucibleless floating zone method with the evaporation of metal and gas-forming impurities was analyzed. It was noted that a good degree of purification from volatile metal impurities was achieved at high zone velocities. For this impurities the saturated vapor pressure $p_{0}$ at the melting point of zirconium is quite high $\left(>1 \cdot 10^{-1} \mathrm{~Pa}\right)$. The melting at a speed of 16 or 8 $\mathrm{mm} / \mathrm{min}$ allowed to significantly reduce the content of $\mathrm{Al}, \mathrm{Ca}, \mathrm{Cu}, \mathrm{Fe}, \mathrm{Mn}, \mathrm{Ni}, \mathrm{Si}, \mathrm{Ti}, \mathrm{Cr}$ and other metals.

For purification from refractory metal impurities and impurities that have a low saturated vapor pressure at the melting point of zirconium, a multistage zone recrystallization is required. Multiple passes with low velocity $(4,2$, and $1 \mathrm{~mm} / \mathrm{min})$ will reduce their concentrations.

Theoretical postulates of refining process of substances under effect of direct electric field were considered in a number of books and articles [7-9]. An application of direct electric current to metal sample leads to moving both the matrix ions and impurity ones in a certain direction (to anode or cathode). The direct electric current, which passing through the phase boundary, changes the value of the effective distribution coefficient $k_{e}$. It happens due to the addition to the diffusion flow of the electrotransport component.

In general, the resultant force $F$, which acts on the impurity ion in the base metal substrate, can be expressed as:

$$
F=(Z-|e| n L \sigma) E=Z^{*} E,
$$

where $Z$ is the ion charge; $e$ is the electron the expression for the impurity ion mobility can be represented in the form as:

$$
U=v^{\prime} / E \text {. }
$$

Equation (4) for the effective distribution coefficient of the impurity in the case of zone melting in an electric field becomes:

$$
k^{\prime}=\frac{1+\frac{v^{\prime}}{v}}{1+\left[\frac{1}{k_{0}}\left(1+\frac{v^{\prime}}{v}\right)-1\right] \cdot e^{-\frac{v \delta}{D}\left(1+\frac{v^{\prime}}{v}\right)}},
$$

where $D$ is the diffusion coefficient of the impurity ion, $v^{\prime}$ is the velocity of the impurity ion.

The value of the effective coefficient $k_{e}$ under conditions of applying an electric field is mainly affected by such processes: 1) displacement of impurities with $k_{0}<1$ during zone recrystallization; 2) the influence of the flux arising due to different mobility of the base ions and impurity ions (the magnitude of the flux is proportional to $v^{\prime}$ ) [3].

Thus, under the influence of an electric field, the magnitude of $k_{e}$ can change. This makes it possible to 
obtain the following results: 1) the value of $k_{e}$ can be changed, and thus there is increase of the efficiency of refining; 2) the value of $k_{e}$ can be made smaller than unity (even for those cases where $k_{0}>1$ ), which makes it possible to refine from impurities during recrystallization.

It should be noted that when performing calculations according to formula (7), some effects are not taken into account, which may occur at the "liquid-solid" interface and may affect the magnitude of $k_{e}$. For example, the Peltier effect (heat generation or absorption at the phase boundary) is not considered. In this case an additional impurity flow occurs, caused by diffusion under a thermal gradient field, and this may affect the efficiency of cleaning.

In the work [11], there was a study of the displacement of interstitial impurities in the lowtemperature and high-temperature solid phases of zirconium under the influence of a constant electric current. The alloys with a high content of oxygen, carbon and nitrogen were prepared by the arc melting method. The bars in the form of wires were having dimensions of $6.6 \mathrm{~cm}$ in length and $0.26 \mathrm{~cm}$ in diameter. Many hours of annealing was applied at various temperatures under conditions of transmission of electric current with these bars. As a result of studying the impurity composition of the samples, the effective charge $Z^{*}$, mobility $U$, displacement velocity $v^{\prime}$, and diffusion coefficient $D$ for carbon, nitrogen and oxygen ions were calculated. The interstitial impurities were displaced to the anode during electric transport. It was allowed to determine the value and sign of the effective ion charge $\left(Z^{*}<0\right)$.

The authors explained the divergence in the calculated and experimental data on the concentration of interstitial impurities by the absorption of residual gases from the chamber atmosphere.

In the studies presented below, the process of zirconium refining was carried out by the method of zone recrystallization in an electric field. The description of the process and the experimental setup was considered in detail in the article [12].

Zirconium obtained in the course of industrial iodide refining was used as a starting material for experiments (with a purity of $99.8 \mathrm{wt} . \%$ ).

The results of the impurity content in zirconium were obtained by laser mass spectrometry. The analysis used an energy analyzer EMAL-2. The limiting sensitivity of the method of analysis for metallic impurities was $\sim 10^{-5} \ldots 10^{-6}$ at. $\%$.

The use of a LECO TC-600 gas analyzer made it possible to determine the content of nitrogen and oxygen in the samples with an accuracy of $5 \cdot 10^{-8}$ at. $\%$. The device was calibrated with certified LECO samples.

Visual viewing of thin sections and photographing of the grain structure was carried out using an MMP-4 microscope.

Microhardness was measured on a PMT-3 microhardness meter at loads of 0.05 and $0.1 \mathrm{kG}$. The microhardness numbers were recorded in ten measurements; the measurement error did not exceed $5 \%$

\section{RESULTS AND DISCUSSION}

Analysis of the state diagrams of "zirconiumimpurity" binary systems allows to conclude that for the $\mathrm{Zr}-\mathrm{O}$ and $\mathrm{Zr}-\mathrm{O}$ cases, the value of $k_{0}>1$. So, up to the oxygen content of $10 \%$ and nitrogen $4.4 \%$, the melting point of the alloy increases with increasing of impurity concentration (Fig. 1).
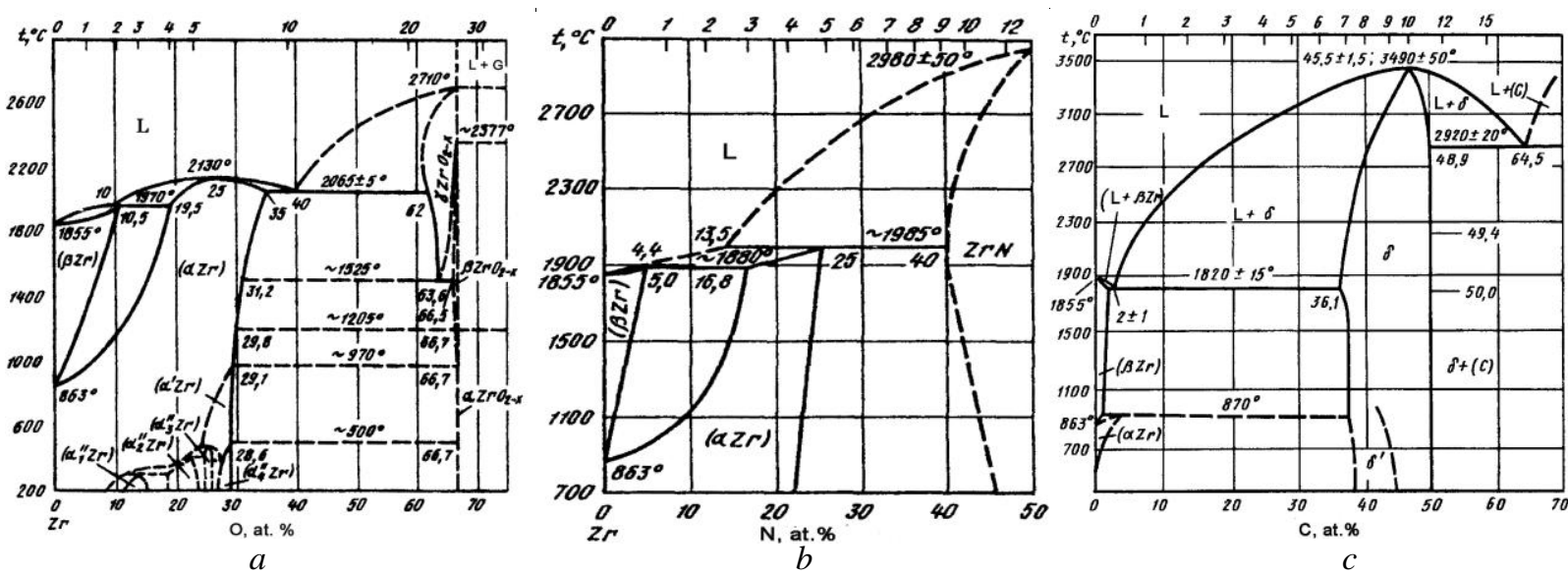

Fig. 1. The state diagrams for systems $\mathrm{Zr}-\mathrm{O}(\mathrm{a}), \mathrm{Zr}-\mathrm{N}(\mathrm{b})$, and $\mathrm{Zr}-\mathrm{C}(\mathrm{c})$

It is characteristic of the $\mathrm{Zr}-\mathrm{C}$ diagram that, to a carbon concentration of $1 \ldots 2 \%$, the melting point of the alloy decreases, and in this case $k_{0}<1$ [13].

In the samples with whose it was carried out the refining in the present work, the concentration of interstitial impurities (oxygen, carbon, nitrogen) was less than $0.3 \%$. Therefore, in the diagrams, a region with a low impurity concentration was considered.
The distribution coefficients for metallic impurities and interstitial impurities in zirconium were calculated taking into account the thermodynamic constants of the ideal solution equation. By the formula (2), the values of the equilibrium coefficient $k_{0}$ are calculated. To calculate the value of the effective coefficient $k_{e}$, formula (3) was used.

The calculations took into account the value of the 
melting point of zirconium $T_{b}=2125 \mathrm{~K}, T_{m}$ is element melting point, $T_{G}$ is estimated value of the melting temperature of the base-impurity alloy, $\Delta H$ is the molar heat of fusion of the impurity, the ratio $\delta / d \approx 200 \mathrm{~s} / \mathrm{cm}$, and the melting speed $v=0.0033 \mathrm{~cm} / \mathrm{s}$

The results are presented in Table 1 , in which $k_{0}$ values were taken from the reference book [14] for comparison.

Table 1

The results of calculating the equilibrium and effective coefficients for impurities in zirconium

\begin{tabular}{|c|c|c|c|c|c|c|}
\hline Element & $T_{m}, \mathrm{~K}$ & $T_{G}, \mathrm{~K}$ & $\begin{array}{c}\Delta H, \\
\mathrm{~kJ} / \mathrm{mol}\end{array}$ & $k_{0}$ & $k_{0}[14]$ & $k_{e}$ \\
\hline Oxygen & - & 2243 & 96 & 1.33 & $>1$ & 1.15 \\
\hline Carbon & - & 2093 & 110 & 0.91 & - & 0.95 \\
\hline Nitrogen & - & 2153 & 83,736 & 1.06 & $>1$ & 1.03 \\
\hline Hafnium & 2500 & 2500 & 25.1 & 1.23 & $>1$ & 1.1 \\
\hline Aluminum & 933.5 & 933.5 & 10.75 & 0.46 & $<0.42$ & 0.62 \\
\hline Iron & 1812 & 1201 & 13.8 & 0.54 & 0.27 & 0.70 \\
\hline Calcium & 1112 & 1112 & 9.2 & 0.62 & - & 0.76 \\
\hline Silicon & 1687 & 1643 & 50.6 & 0.43 & $<1$ & 0.59 \\
\hline Molybdenum & 2890 & 1826 & 28 & 0.77 & 0.39 & 0.87 \\
\hline Nickel & 1728 & 1233 & 17.61 & 0.49 & $<1$ & 0.65 \\
\hline Titanium & 1943 & 1808 & 18.8 & 0.83 & $<1$ & 0.90 \\
\hline Chromium & 2136 & 1605 & 21 & 0.68 & $<1$ & 0.80 \\
\hline
\end{tabular}

Refining of zirconium was carried out by the method of vacuum electron beam melting in an electric field, turned on against the zone. With this option of connecting the field, the ions of interstitial impurities, characterized by a negative value of $Z^{*}$, were shifted to the positive pole (anode). Moreover, the movement of ions coincided with the motion direction of the liquid zone. The effectiveness of the ZMEF process with this method of connecting an electric field was previously confirmed when working with hafnium materials [15].

Using the recommendations of the article [11] (the values of effective charge $Z^{*}$ and of the diffusion coefficient of the impurity ion $D$ ) the mobility of the impurity ion $U$ were calculated using formula (5). According to formula (6) it was possible to calculate the movement velocity of the impurity ion $v^{\prime}$. The calculation of the effective coefficient $k_{e}^{\prime}$ for interstitial impurities in the case of ZMEF was carried out according to formula (7).

In the estimations it was taken into account that in the liquid phase of the main material the values of the mobility of the impurity ion $U$, diffusion coefficient $D$, effective charge $Z^{*}$ may differ from the values characteristic of the low-temperature $\alpha$ - and hightemperature $\beta$-phases of zirconium. In particular, the values of $U$ and $D$ can increase significantly. The estimates of the values of these parameters for the liquid phase of zirconium have not been carried out previously. Therefore, the calculations performed in the work can only give an indicative estimates of the values.

In the calculation the characteristic parameter values for the experiment were used: the electric field intensity $E=0.013 \mathrm{~V} / \mathrm{cm}$, melting speed $v=0.066 \mathrm{~cm} / \mathrm{s}$. The calculation results are presented in Table 2.

Table 2

The calculation results of the ZMEF parameters for interstitial impurities in zirconium

\begin{tabular}{|c|c|c|c|c|c|c|c|}
\hline \multirow{2}{*}{ Impurity } & $Z^{*}$ & $\begin{array}{c}U, 10^{-5}, \\
\mathrm{~cm}^{2} /(\mathrm{V} \cdot \mathrm{s})\end{array}$ & $\begin{array}{c}D, 10^{-6}, \\
\mathrm{~cm}^{2} / \mathrm{s}\end{array}$ & $\begin{array}{c}\left|v^{\prime}\right|, 10^{-7}, \\
\mathrm{~cm} / \mathrm{s}\end{array}$ & $\begin{array}{c}k_{e} \\
\text { at ZM }\end{array}$ & $\overrightarrow{\mathrm{E}} \uparrow \uparrow \vec{v}$ & $\overrightarrow{\mathrm{E}} \uparrow \downarrow \overrightarrow{\mathrm{v}}$ \\
\hline Oxygen & -1 & 1.8 & 3.3 & 2.34 & 1.15 & 1.01 & 0.99 \\
\hline Carbon & -0.2 & 0.9 & 8.25 & 1.17 & 0.95 & 0.96 & 0.95 \\
\hline Nitrogen & -0.7 & 1.2 & 3.14 & 1.56 & 1.03 & 1.01 & 0.99 \\
\hline
\end{tabular}

The calculations $k_{e}^{\prime}$ for ZMEF show that for gasforming impurities with a negative value of the effective charge $Z^{*}$, refining will proceed more efficiently when an electric field is applied against the direction of the zone melting course. The values of the effective coefficient for oxygen and nitrogen in this case can change and become less than unity. This shows the possibility of refining from these impurities during electric transport.

In preparation for experimental work, preforms were previously cut from a bar of iodide zirconium with a diameter of $20 \mathrm{~mm}$. The bar was cut lengthwise into four segments with a length of 150 to $300 \mathrm{~mm}$ using electric spark cutting. 
The preparation of refined samples at the crucibleless zone melting facility was carried out under various conditions. Before the start of the process or during the experiment, it was possible to change:

1) the vacuum conditions from $1 \cdot 10^{-1}$ to $1 \cdot 10^{-4} \mathrm{~Pa}$,

2) the melting speed from 16 to $1 \mathrm{~mm} / \mathrm{min}$,

3 ) the number of passes from one to five,

4) the value of the potential difference between the cathode of the electron beam gun and the ingot from 4 to $10 \mathrm{kV}$,

5) the direction of the electric field along or against the course of zone melting,

6) the value of the constant electric current passing through the sample is from 20 to $100 \mathrm{~A}$.

The stages of high-temperature heating (from half an hour to 2 hours) and of zone melting of the workpiece at a speed of $16 \mathrm{~mm} / \mathrm{min}$ made it possible to obtain a cylindrical ingot.

The meltings with high (16 or $8 \mathrm{~mm} / \mathrm{min}$ ) and low speed $(4,2$, and $1 \mathrm{~mm} / \mathrm{min})$ reduced the content of both metallic impurities and interstitial impurities in zirconium significantly [6].

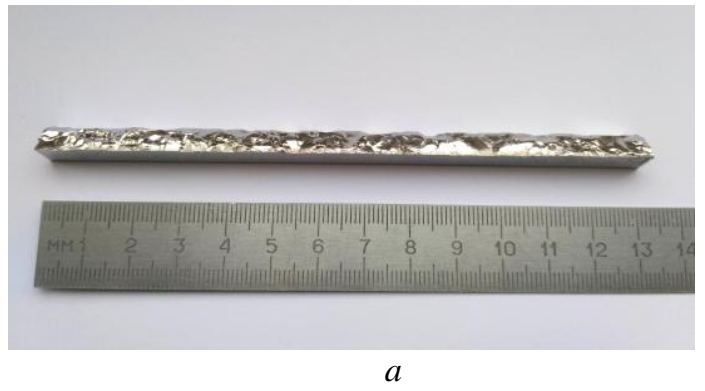

The complex methodology of the refining process included the application of thermal cycling (heating and cooling of the ingot in the polymorphic temperature range $\alpha-\beta$ transformations) at the final stage. This procedure contributed to the increase in grain size.

Zone melting in an electric field was carried out with zirconium ingots round in cross section with a zone velocity of 2 to $8 \mathrm{~mm} / \mathrm{min}$.

The refining of $\mathrm{Zr}$ during $\mathrm{ZMEF}$ occurred as a result of the simultaneous passage of several physical processes:

1) evaporation of impurities during zone melting in vacuum;

2) the displacement of metallic impurities, as well as oxides and carbides, in the end part of the sample during recrystallization;

3 ) the movement of ions of interstitial impurities to the anode.

Photos of the initial iodide zirconium and the sample refined by the ZMEF method are presented in Fig. 2. The ingot was obtained as a result of three passes ZM and two ZMEF.

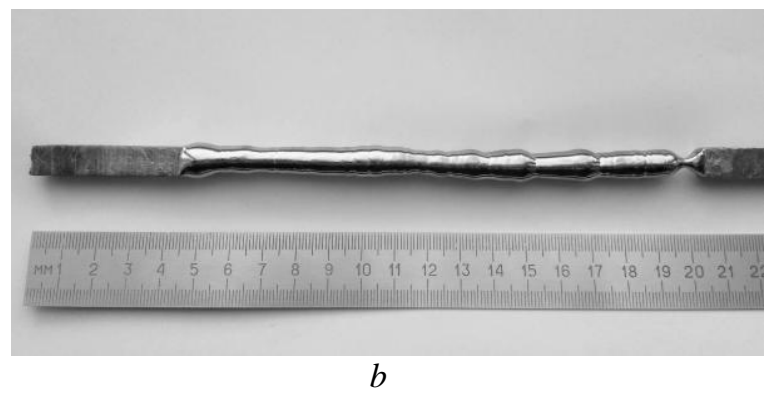

Fig. 2. The shapes of the initial iodide zirconium (a) and the metal ingot refined by the ZMEF method $(b)$

Samples in the form of tablets were cut out from the middle (cleanest) part of the refined ingot for conducting elemental composition and metallography studies $(6 \mathrm{~mm}$ high and $8 \mathrm{~mm}$ in diameter). The results of the analysis of the content of impurities in the zirconium samples before and after refining are given in
Table 3. The bottom row of the table shows the calculation of the efficiency of the zone melting process with electric transport (in relation to the concentration of impurities in the initial metal to the concentration in the refined material).

The results of elemental analysis of zirconium samples

Table 3

\begin{tabular}{|c|c|c|c|c|c|c|c|c|c|c|c|c|}
\hline \multirow{2}{*}{ Zirconium } & \multicolumn{10}{|c|}{ The concentration, wt.\% } \\
\cline { 2 - 14 } & $\mathrm{Zr}$ & $\mathrm{Hf}$ & $\mathrm{O}$ & $\mathrm{C}$ & $\mathrm{N}$ & $\mathrm{Al}$ & $\mathrm{Fe}$ & $\mathrm{Ni}$ & $\mathrm{Cu}$ & $\mathrm{Cr}$ & $\mathrm{Si}$ & $\mathrm{Ti}$ \\
\hline Initial & 99.80 & 0.075 & 0.052 & 0.02 & 0.003 & $2 \cdot 10^{-4}$ & 0.008 & 0.004 & $9 \cdot 10^{-4}$ & $3 \cdot 10^{-3}$ & $2 \cdot 10^{-4}$ & $5 \cdot 10^{-4}$ \\
\hline $\mathrm{ZM}$ & 99.87 & 0.052 & 0.026 & 0.012 & 0.0015 & $7 \cdot 10^{-5}$ & $7 \cdot 10^{-4}$ & 0.0023 & $2 \cdot 10^{-5}$ & $5 \cdot 10^{-5}$ & $7 \cdot 10^{-5}$ & $3 \cdot 10^{-4}$ \\
\hline ZMEF $\overrightarrow{\mathrm{E}} \uparrow \downarrow \vec{v}$ & 99.91 & 0.05 & 0.016 & 0.01 & 0.001 & $4 \cdot 10^{-5}$ & $6 \cdot 10^{-4}$ & 0.002 & $2 \cdot 10^{-5}$ & $4 \cdot 10^{-5}$ & $2 \cdot 10^{-5}$ & $2 \cdot 10^{-4}$ \\
\hline $\begin{array}{c}\text { Efficiency } \\
\text { ZMEF }\end{array}$ & & 1.5 & 3.3 & 2 & 3 & 5 & 11 & 2 & 45 & 75 & 10 & 2.5 \\
\hline
\end{tabular}

The results of the analysis of the elemental composition show an insignificant content in the refined ingots of a number of metallic impurities that were removed during the simultaneous passage of the processes of evaporation, zone recrystallization, and melting in an electric field. So, the aluminum concentration was reduced by 5 , iron -11 , nickel -2 , copper -45 , chromium -75 , silicon -10 , titanium -2.5 times.
Elemental analysis showed a slight decrease in hafnium concentration (from 0.075 to $0.05 \mathrm{wt} . \%$ ). The content of molybdenum and niobium after melting did not changed and remained at the level of $2 \cdot 10^{-4}$ and $1 \cdot 10^{-4}$ wt. $\%$ respectively.

The refining of zirconium from gas-forming impurities occurred at various stages of the experiment. So, hydrogen left in the form of gaseous molecules of $\mathrm{H}_{2}, \mathrm{H}_{2} \mathrm{O}$ upon preliminary heating and zone melting at a high speed. Carbon escaped in the form of $\mathrm{CO}$ and $\mathrm{CO}_{2}$ 
molecules. The refining process also occurred due to the displacement of metal carbides into the end part of the ingot. Nitrogen evaporated in the form of $\mathrm{N}_{2}$ gas molecules during high-temperature heating and zone melting.

A decrease in the oxygen content occurred at the stages of heating and zone melting as a result of the formation of gaseous molecules $\left(\mathrm{CO}, \mathrm{CO}_{2}, \mathrm{H}_{2} \mathrm{O}\right)$. The purification from oxygen could also occur due to a displacement upon recrystallization to the end of the sample of refractory oxides (for example, $\mathrm{ZrO}_{2}, \mathrm{HfO}_{2}$ ).

In the purest zirconium samples the oxygen concentration decreased by 3.3 , nitrogen -3 , carbon -2 times. The purity of the samples refined by the ZMEF method was characterized by a value of $99.91 \mathrm{wt} \%$ by zirconium content.
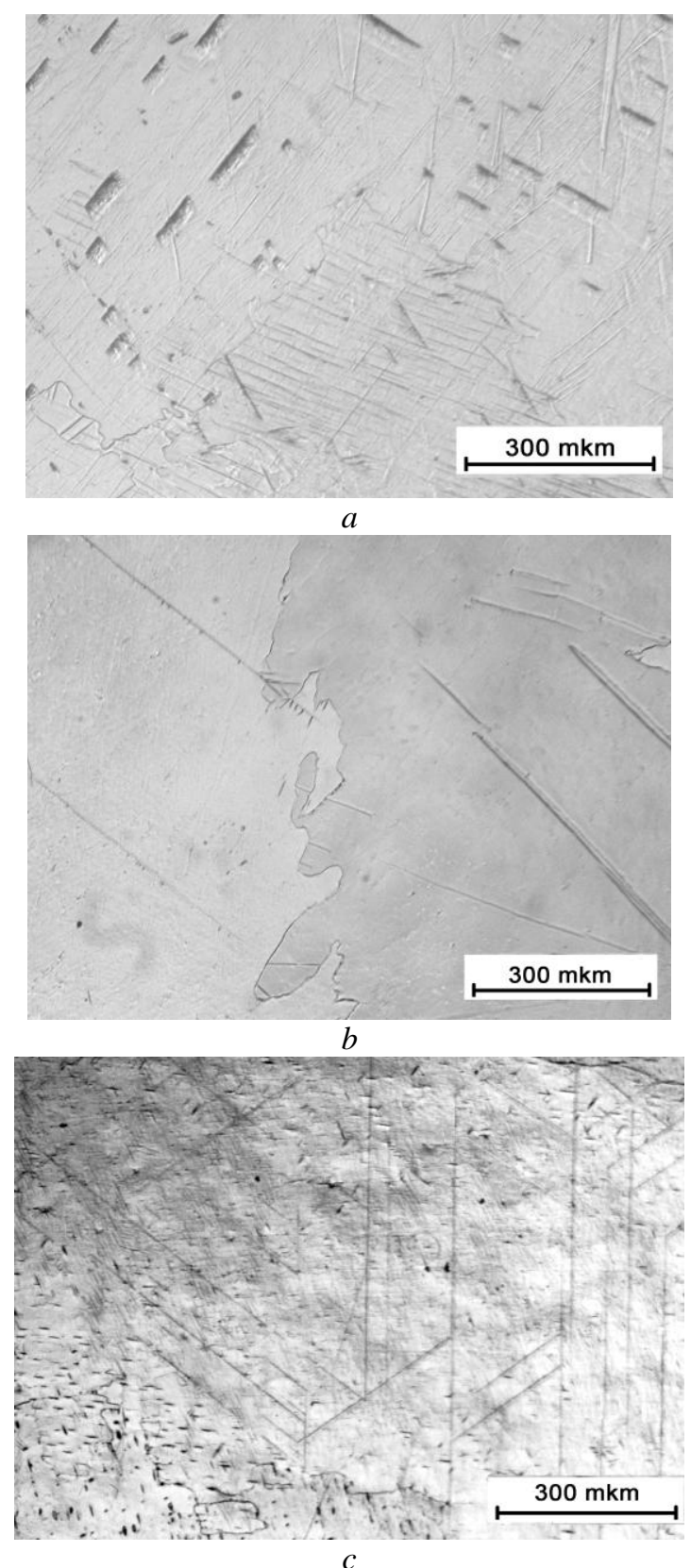

Fig. 3. The microstructure of the samples of the initial iodide zirconium (a), refined by the methods of $Z M(b)$ and $\mathrm{ZMEF}(\mathrm{c})$ materials
Fig. 3 presents photographs of the microstructure of zirconium iodide, as well as samples cut from ingots refined by the ZM and ZMEF methods.

Coarse grains elongated along the melting direction with a length of $12 \mathrm{~mm}$ and a cross section of up to $4 \mathrm{~mm}$ were observed in the zone-melted material. After recrystallization, twins were present in the grains. An insignificant amount of impurities accumulated along the grain boundaries (see Fig. 3,b).

After ZMEF in microphotographs it was possible to see the presence of zirconium grains from 2 to $5 \mathrm{~mm}$ in size, the borders are clean. The impurities were redistributed from the boundaries along the body of the grains. It can be explained by a consequence of the influence of electric transport. In the micrograph (see Fig. 3,c) one can see the output of the primary slip lines along the prismatic planes $\{10 \overline{1} 0\}$.

The microhardness value for the samples of the initial iodide zirconium varied within $H_{\mu}=980 \ldots 1110 \mathrm{MPa}$. The scatter of values is due to the multidirectional grain growth during iodide refining.

After zone recrystallization the grain of the material became cleaner, impurities accumulated along the grain boundaries. The grains were mainly aligned along the direction of the zone melting (the deviation of the normal vector to the base plane from the direction of melting was from 0 to 15 degrees). The microhardness value was $H_{\mu}=930 \ldots 980 \mathrm{MPa}$.

After melting in an electric field the spread of microhardness values increased due to the redistribution of impurities over the grain body $\left(H_{\mu}=880 \ldots 1040 \mathrm{MPa}\right)$ (Fig. 4).

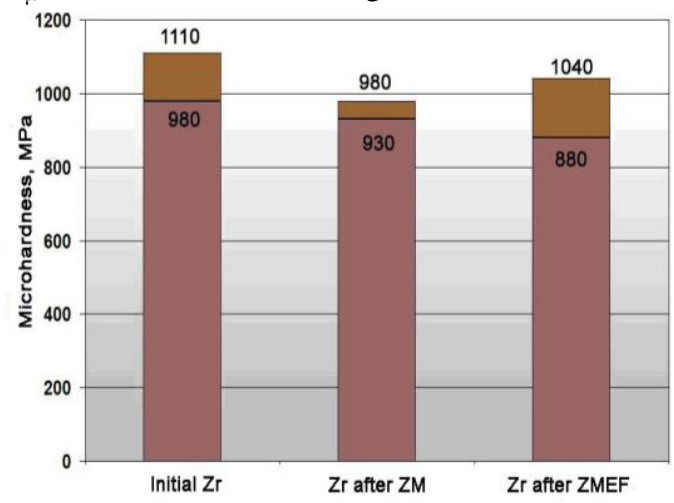

Fig. 4. The microhardness value for the initial iodide zirconium and materials after ZM and ZMEF

\section{CONCLUSIONS}

The physical substantiation of the refining process of zirconium from metallic and interstitial impurities by methods of zone melting and melting in an electric field is presented. A technique was applied, including vacuum crucibleless zone melting with electron-beam heating, thermal cycling in the temperature range of polymorphic transformation, and melting in an electric field. It was made possible to obtain zirconium samples with a purity of 99.91 wt.\%. The concentration of interstitial impurities was reduced significantly (oxygen in 3.3 , nitrogen -3 , carbon -2 times). The change in the microstructure and microhardness of zirconium after refining by zone melting and melting in an electric field is studied. 


\section{REFERENCES}

1. А.С. Займовский, Е.В. Никулина, Н.Г. Решетников. Циркониевые сплавы в атомной энергетике. М.: «Энергоатомиздат», 1994, $453 \mathrm{c}$.

2. D.L. Douglass. The Metallurgy of Zirconium. Vienna: IAEA, 1971, 466 p. $366 \mathrm{c}$.

3. В. Пфанн. Зонная плавка. М.: «Мир», 1970,

4. Р. Лодиз, Р. Паркер. Рост монокристаллов. М.: «Мир», 1974, 540 с.

5. А.Н. Несмеянов. Давление пара химических элементов. М.: «Изд-во АН СССР», 1961, 396 с.

6. О.Е. Кожевников, Н.Н. Пилипенко, В.Д. Вирич, Ю.С. Стадник и др. Физическое обоснование и экспериментальное исследование рафинирования циркония методом зонной перекристаллизации // Вопросы атомной науки и техники. Серия «Физика радиачионных повреждений и радиационное материаловедение». 2018, №5(117), с. 62-68.

7. В.А. Михайлов, Д.Д. Богданова. Электроперенос в жидких металлах. Новосибирск: «Наука», 1978, $224 \mathrm{c}$.

8. В.Б. Фикс. Ионная проводимость в металлах и полупроводниках. М.: «Наука», 1969, 215 с.

9. G.P. Kovtun. Electrotransport as a way of metals deep purification // East Eur. J. Phys. 2014, v. 1, N 1, p. 37-46.

10. J. Verhoeven. Electrotransport as a Means of Purifying Metals // J. Metals. 1966, v. 18, N 1, p. 26-31.
11. F. Schmidt,
O. Carlson,
C. Swanson.

Electrotransport of Carbon, Nitrogen, and Oxygen in Zirconium // Metallurgical Transactions. 1970, v. 1, p. 1371-1374.

12. П.Н. Вьюгов, О.Е. Кожевников, Т.Ю. Рудычева. Получение высокочистых образцов гафния методом бестигельной зонной плавки // Bonpocbl атомной науки и техники. Серия «Вакуум, чистые материаль, сверхпроводники». 2009, №6(18), с. 1924.

13. Диаграммы состояния двойных металлических систем: Справочник: 1-4 т. / Под ред. Н.П. Лякишева. М.: «Машиностроение», 19962000.

14. И. Бартел, Э. Буриг, К. Хайн, Л. Кухарж. Кристаллизаџия из расплавов. М.: «Металлургия», 1987, 320 c.

15. О.Е. Кожевников, П.Н. Вьюгов, Н.Н. Пилипенко. Рафинирование гафния методом зонной плавки в электрическом поле // Bопросы атомной науки и техники. Серия «Физика радиационных повреждений и радиационное материаловедение». 2015, №2, с. 89-94.

Article received 24.10.2019

\section{ЗОННОЕ РАФИНИРОВАНИЕ ЦИРКОНИЯ В ЭЛЕКТРИЧЕСКОМ ПОЛЕ}

\section{О.Е. Кожевников, Н.Н. Пилипенко, Ю.С. Стадник, Р.В. Ажажа}

Представлены физическое обоснование и экспериментальное исследование эффективности применения метода зонной перекристаллизации в электрическом поле для рафинирования циркония от металлических и газообразующих примесей. Исследованы изменения элементного состава, микротвердости и структуры получаемых слитков. Показано, что применение метода позволяет значительно снизить содержание примесей внедрения и получить образцы циркония чистотой 99,91 мас.\%.

\section{ЗОННЕ РАФІНУВАННЯ ЦИРКОНІЮ В ЕЛЕКТРИЧНОМУ ПОЛІ}

\section{О.С. Кожевніков, М.М. Пилипенко, Ю.С. Стаднік, Р.В. Ажажа}

Представлено фізичне обгрунтування та експериментальне дослідження ефективності застосування методу зонної перекристалізації в електричному полі для рафінування цирконію від металевих та газоутворюючих домішок. Досліджено зміни елементного складу, мікротвердості та структури одержуваних злитків. Показано, що застосування методу дозволяє значно знизити вміст домішок впровадження i отримати зразки цирконію чистотою 99,91 мас.\%. 